Research Article

\title{
To evaluate the analgesic activity of resveratrol in different doses in animal model
}

\author{
Tanu Garg ${ }^{1}$, Vijay $\operatorname{Yadav}^{1}$, Rekha Mehani $^{2}$
}

\begin{abstract}
${ }^{1}$ Department of Pharmacology, People's College of Medical Sciences and Research Centre, Bhanpur, Bhopal, India ${ }^{2}$ Department of Pharmacology, RKDF, MCH, RC, Bhopal, India
\end{abstract}

Received: 08 March 2016

Accepted: 08 April 2016

\section{*Correspondence to:}

Dr. Tanu Garg,

Email: tanu43210@gmail.com

Copyright: (C) the author(s), publisher and licensee Medip Academy. This is an openaccess article distributed under the terms of the Creative Commons Attribution NonCommercial License, which permits unrestricted noncommercial use, distribution, and reproduction in any medium, provided the original work is properly cited.

\begin{abstract}
Background: Pain is a complex unpleasant phenomenon composed of sensory experiences originating from damaged tissue or abnormal physiological condition. The objective of this study was to evaluate the analgesic activity of resveratrol in different doses in animal model.

Methods: Albino mice of either sex weighing 20-30 gms were selected for the study. Mice were divided into 4 groups of 6 animals each. The control group received $0.9 \%$ normal saline $(10 \mathrm{ml} / \mathrm{kg})$, standard group received indomethacin $(10 \mathrm{mg} / \mathrm{kg})$ and test groups received resveratrol $(50 \mathrm{mg} / \mathrm{kg}$ and $100 \mathrm{mg} / \mathrm{kg})$. The drugs were given orally 1 hour prior to the tests. The animals were tested for analgesia activity 30,60, 90, 120 minutes after drug administration using tail flick method and $1 \%$ acetic acid was given intraperitoneally to induce writhing in the other method. Delay in the reaction time in tail flick method and decrease in total number of writhes in acetic acid induced writhing model denoted analgesic activity. Data analysis was done using one way ANOVA followed by Tukey's HSD test. $\mathrm{P}<0.05$ was considered as statistically significant.

Results: Resveratrol showed significant increase in reaction time at various time periods in tail flick method and showed significant decrease in the number of writhes in acetic acid induced writhing method.

Conclusions: In the study, resveratrol exhibited analgesic activity in both thermal and chemical pain models in both the doses, and analgesic activity in higher dose $(100 \mathrm{mg} / \mathrm{kg})$ was comparable to standard drug.
\end{abstract}

Keywords: Analgesic, Resveratrol, Writhing

\section{INTRODUCTION}

Pain is a complex unpleasant phenomenon composed of sensory experiences originating from damaged tissue or abnormal physiological condition. ${ }^{1}$ Every individual experiences pain in one or various forms in their life time. The principal objective of the treatment of pain is to remove or abolish the cause of pain. Most commonly used analgesics are Non-steroidal anti-inflammatory drugs and opioids. Analgesic drugs relieve pain without affecting the cause of pain.
Current analgesic therapies though are effective in pain relief have considerable side effects. Thus, there is always the need of search for new analgesics which control the pain effectively with less of the side effects.

Medicinal plants are believed to be the important source of new chemical substances with potential therapeutic efficacy. Resveratrol is one such agent.

Resveratrol is a phytoalexin produced by a wide variety of plants such as grapes, peanuts, berries and medicinal plants, such as Japanese knotweed and is also found in red wine. Apart from its cardio protective effect, 
resveratrol also exhibits other physiological and biochemical properties like anti-oxidant, antiinflammatory, anticancer, anti-aging and neuroprotective effect. $^{2,3}$

The objective of this study was to study the analgesic activity of resveratrol in different doses in animal model.

\section{METHODS}

\section{Animals}

Mice of both sexes weighing 20-30 gms were used in the study. Mice were obtained from the animal house of People's college of medical sciences and research centre, Bhopal. Mice were maintained under standard lab conditions and had free access to food and water.

The study was conducted after taking permission from institutional animal ethics committee (IAEC) and as per the CPCSEA guidelines.

For demonstration of analgesic activity, animals were divided into 4 groups of 6 animals each.

Group 1: control group (10 ml/kg 0f 0.9\% normal saline) Group 2: indomethacin $10 \mathrm{mg} / \mathrm{kg}$

Group 3: resveratrol (test drug) in the dose of $50 \mathrm{mg} / \mathrm{kg}$

Group 4: resveratrol in the dose of $100 \mathrm{mg} / \mathrm{kg}$

All the drugs were given orally.

The mice were numbered and weighed properly.

Antinociceptive effect was measured by chemical and thermal methods.

I. Acetic acid induced writhing

II. The tail-flick test using Radiant heat

I. Acetic acid induced writhing in mice ${ }^{4}$

The animals were pre-treated orally with vehicles or drugs 60 minutes before induction of writhing.

Writhing was induced by intraperitoneal injection of acetic acid (1\% v/v in distilled water) in volume of 10 $\mathrm{ml} / \mathrm{kg}$ body weight. The numbers of writhes per animal were counted for the next 10 minutes. Writhes were characterized by stretching behaviour i.e. a series of constrictions that travel along the abdominal wall, sometimes accompanied by turning movements of the body and extensions of the hind limbs. For scoring, a writhe was indicated by stretching of the abdomen with simultaneous stretching of at least one hind limb. ${ }^{5}$ A significant reduction of writhes in test group compared to those in the control group was considered as an antinociceptic response.
Percentage protection against abdominal constriction was taken as an index of analgesia.

It was calculated as

$\frac{\text { Number of writhing in control group }- \text { Number of writhing in treated group }}{x} \times 100$ Number of writhing in control group

\section{Tail Flick method ${ }^{6,7}$}

This experiment was carried out by using analgesiometer. Mice were placed into animal restrained with the tail exposed. The tip of the tail was placed on the source of radiant heat. The tail withdrawal from heat (flicking response) was taken as the end point. A cut off period of 10 seconds was observed to avoid damage to the tail. ${ }^{6}$

The test and standard drugs were given orally. Response was observed before drug administration and at 30, 60, 90 and 120 minutes after drug administration. Each mouse served as its own control.

A lengthening of the reaction time was interpreted as an analgesic action of the drug. ${ }^{5}$

At each time interval, those animals that showed higher reaction time than the time before drug administration were regarded as positive.

\section{Statistical analysis}

The results are expressed as Mean \pm SD. Results were analysed statistically by one way ANOVA followed by Tukey's HSD test. The difference was considered significant at $\mathrm{p}<0.05$.

\section{RESULTS}

- Acetic acid induced writhing method

Standard drug and test drug in doses $50 \mathrm{mg} / \mathrm{kg}$ and 100 $\mathrm{mg} / \mathrm{kg}$ significantly $(\mathrm{p}<0.0001)$ reduced the number of writhes induced by injection of acetic acid.

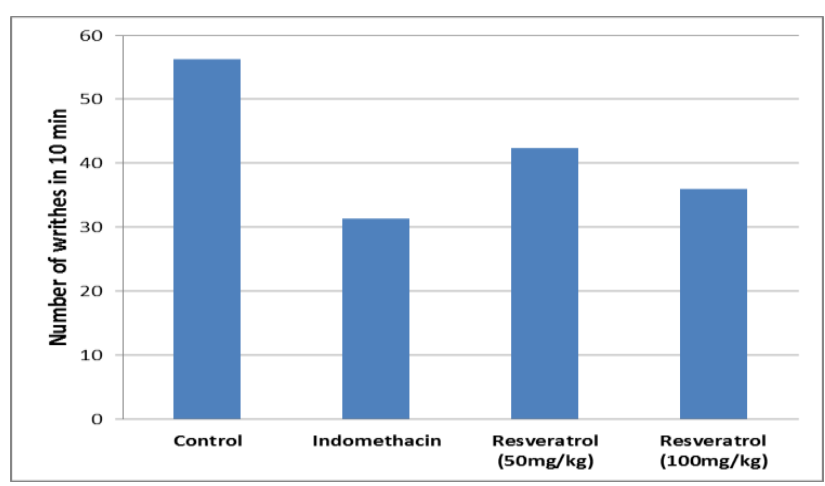

Figure 1: Number of writhes in $\mathbf{1 0}$ minutes in acetic acid induced writhing. 
Standard drug indomethacin showed $44.3 \%$ inhibition of writhing, while resveratrol showed $24.85 \%$ and $36.09 \%$ in doses of $50 \mathrm{mg} / \mathrm{kg}$ and $100 \mathrm{mg} / \mathrm{kg}$ respectively (Table 1 and Figure 1).

Table 1: Table showing analgesic activity in acetic acid induced writhing in mice.

\begin{tabular}{|c|c|c|c|c|c|}
\hline Group & Drug & Dose (mg/kg) & No. of writhes in 10 minutes (Mean \pm SD) & $\%$ inhibition & P value \\
\hline Control & $0.9 \% \mathrm{NS}$ & $10 \mathrm{ml} / \mathrm{kg}$ & $56.33 \pm 2.749$ & - & \multirow{4}{*}{$<0.0001$} \\
\hline Standard & Indomethacin & 10 & $31.33 \pm 2.981 *$ & 44.38 & \\
\hline Test-1 & Resveratrol & 50 & $42.33 \pm 2.494^{*}$ & 24.85 & \\
\hline Test-2 & Resveratrol & 100 & $36 \pm 2 *$ & 36.09 & \\
\hline
\end{tabular}

$* \mathrm{p}<0.05$ as compared to control group

Table 2: Analgesic activity by tail flick response.

\begin{tabular}{|c|c|c|c|c|c|c|c|c|c|}
\hline \multirow{2}{*}{ Group } & \multirow{2}{*}{ Drug } & \multirow{2}{*}{$\begin{array}{l}\text { Dose } \\
(\mathrm{mg} / \mathrm{kg})\end{array}$} & \multicolumn{5}{|c|}{ Reaction time in second at time (Mean \pm SD) } & \multirow{2}{*}{$\begin{array}{l}P \\
\text { value }\end{array}$} & \multirow{2}{*}{$\begin{array}{l}\text { F } \\
\text { value }\end{array}$} \\
\hline & & & 0 min & $30 \mathrm{~min}$ & $60 \mathrm{~min}$ & $90 \mathrm{~min}$ & $120 \mathrm{~min}$ & & \\
\hline Control & $\begin{array}{l}0.9 \% \\
\text { NS }\end{array}$ & $\begin{array}{l}10 \\
\mathrm{ml}\end{array}$ & $3.67 \pm 0.516$ & $3.5 \pm 0.837$ & $3.83 \pm 0.753$ & $3.67 \pm 0.516$ & $3.17 \pm 0.408$ & 0.445 & 0.963 \\
\hline Standard & $\begin{array}{l}\text { Indom- } \\
\text { ethacin }\end{array}$ & 10 & $3.67 \pm 0.816$ & $4.83 \pm 0.753 *$ & $5.67 \pm 1.033^{* *}$ & $6.0 \pm 1.264^{*}$ & $6.67 \pm 1.033 * *$ & $<0.0001$ & 8.095 \\
\hline Test-1 & $\begin{array}{l}\text { Resve- } \\
\text { ratrol }\end{array}$ & 50 & $3.83 \pm 1.169$ & $4.83 \pm 0.753 *$ & $5.5 \pm 0.548^{*}$ & $5.67 \pm 1.211 *$ & $5.0 \pm 0.632 * *$ & 0.006 & 4.743 \\
\hline Test-2 & $\begin{array}{l}\text { Resv- } \\
\text { eratrol }\end{array}$ & 100 & $3.17 \pm 0.753$ & $5.33 \pm 0.516^{* *}$ & $5.5 \pm 1.049^{*}$ & $6.33 \pm 0.816^{* *}$ & $5.33 \pm 0.816^{* *}$ & $<0.0001$ & 13.543 \\
\hline F value & & & 0.7 & 7.06 & 5.92 & 8.61 & $21.71<0.000$ & & \\
\hline$P$ value & & & 0.563 & 0.002 & 0.005 & 0.001 & 1 & & \\
\hline
\end{tabular}

$* \mathrm{p}<0.05, * * \mathrm{p}<0.01$ as compared to control

- $\quad$ Tail flick response

In tail flick response method using analgesiometer, standard and test drugs (in doses $50 \mathrm{mg} / \mathrm{kg}$ and 100 $\mathrm{mg} / \mathrm{kg}$ ) significantly increased the latency of tail flick as compared to control. (Table 2 and Figure 2).

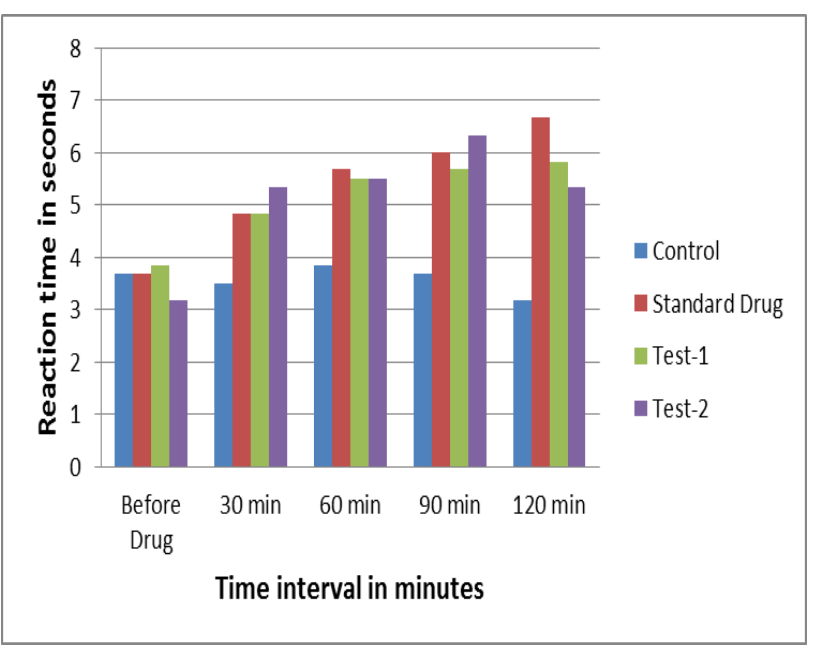

Figure 2: Analgesic activity by tail flick response method.

\section{DISCUSSION}

The present study was carried out to evaluate the antinociceptive effect of resveratrol in different doses.

Resveratrol has been found to be of benefit in chronic pain states seen after inflammatory insults. It exhibited antinociceptive effect by prevention of COX-2 mRNA increase induced by carrageenan Pham-Marcou TA et al and reversed the hyperalgesia induced by local tissue injury provoked by carrageenan in rat hind paw GentilliM et al. 8,9

Not many studies are available exhibiting the selective antinociceptive effect of resveratrol.

The writhing response to intraperitoneally injected acetic acid is a sensitive procedure to establish peripherally acting analgesics. ${ }^{7}$ Intraperitoneal injection of acetic acid produces an abdominal writhing response due to sensitization of chemosensitive peritoneal nociceptors by prostaglandins. $^{7}$

In acetic acid induced writhing method, all the drugs significantly $(p<0.0001)$ reduced the number of writhes. Indomethacin showed the maximum analgesic activity. Resveratrol in doses $50 \mathrm{mg} / \mathrm{kg}$ and $100 \mathrm{mg} / \mathrm{kg}$ also 
showed significant analgesic activity but it was less than the indomethacin.

Tail flick method of analgesia is effective in estimating the efficacy and potency of centrally acting analgesics. ${ }^{7}$ In this study, all the drugs increased the pain threshold significantly and maximum effect was observed with 100 $\mathrm{mg} / \mathrm{kg}$ resveratrol.

The probable mechanism of antinociceptive effect of resveratrol could be the prevention of COX-2 mRNA up regulation as shown in other studies.

\section{CONCLUSION}

Though resveratrol has shown the analgesic activity in doses $50 \mathrm{mg} / \mathrm{kg}$ as well as $100 \mathrm{mg} / \mathrm{kg}, 100 \mathrm{mg} / \mathrm{kg}$ dose has shown analgesic activity to be comparable to that of indomethacin.

Limitation of this study was the less number of animals in each test group.

To effectively conclude the efficacy of resveratrol as an analgesic adjuvant, more studies are required with test groups containing larger number of animals.

Funding: No funding sources Conflict of interest: None declared

Ethical approval: The study was approved by the Institutional Ethics Committee

\section{REFERENCES}

1. Milind P, Monu Y. Laboratory models for screening analgesics. International Research Journal of Pharmacy. 2013;4(1):15-9.

2. Aggarwal BB, Bhardwaj A, Aggarwal RS, Seeram NP, Shishodia S, Takada Y. Role of resveratrol in prevention and therapy of cancer: preclinical and clinical studies. Anticancer Research. 2004;24:2783-840.

3. Smoliga JM, Baur JA, Hausenblas HA. Resveratrol and health-a comprehensive review of human clinical trials. Mol. Nutr. Food Res. 2011;55:1129-41.

4. Mishra D, Ghosh G, Kumar PS, Panda PK. An experimental study of analgesic activity of selective cox-2 inhibitor with conventional NSAIDS. Asian Journal of Pharmaceutical and Clinical Research. 2011;4(1):78-81.

5. Gupta SK. Drug screening methods (Preclinical Evaluation of New Drugs). $2^{\text {nd }}$ edition.

6. Shanmugasundaram P, Venkataraman S. Antinociceptive activity of hygrophila auriculata (Schum) Heine. Afr J Trad. CAM. 2005;2(1):62-9.

7. Vogel HG. Analgesic, anti-inflammatory, and antipyretic activity. In: drug discovery and evaluation: pharmacological assays. $2^{\text {nd }}$ ed. Germany: SpringerVerlag Berlin Heidelberg; 2002:2:669-774.

8. Pham-Marcou TA, Beloeil H, Sun X, Gentili M, Yaici D, Benoit G, et al. Antinociceptive effect of resveratrol in carrageenan-evoked hyperalgesia in rats: prolonged effect related to $\mathrm{COX}-2$ expression impairment. Pain. 2008;140(2):274-83.

9. Gentilli M, Mazoit JX, Bouaziz H, Fletcher D, Casper RF, Benhamou D, et al. Resveratrol decreases hyperalgesia induced by carrageenan in the rat hind paw. Life Sci. 2001;68(11):1317-21.

Cite this article as: Garg T, Yadav V, Mehani

$\mathrm{R}$. To evaluate the analgesic activity of resveratrol in different doses in animal model. Int J Basic Clin Pharmacol 2016;5:869-72. 